\title{
The SMEs Governance Mechanisms Practices and Financial Performance: Case of Tunisian Industrial SMEs
}

\author{
Salah Ben Hamad \\ Doctor in finance, University of Sfax, Tunisia \\ E-mail: benhamad_salah@yahoo.fr \\ Afef Karoui \\ Phd student, Univerrsity of Sfax, Tunisia
}

Received: January 16, 2010 Accepted: February 18, $2011 \quad$ doi:10.5539/ijbm.v6n7p216

\begin{abstract}
Nowadays, the issue of corporate governance occupies central paramount position among the preoccupations of the firms' decision-makers. Noteworthy, the relationship between governance and company performance is often stressed within the context of large companies and very few are those studies dealing with this subject as regard the small and medium enterprises (SME). In fact, most of the studies dealing with the governance question have predominantly out looked this issue with respect to the SME essentially in the context of the emergent countries.

In this setting of analysis, the present research magic objective consists in highlighting the interaction dominating the governance relating mechanisms, namely, the directors' characters, the ownership structure and the directors' board regarding the SME performance.

Actually, an examination of the tests conducted on a sample constituting of 50 Tunisian SMEs has shown that both the ownership structure and the board of directors play a paramountly role in improving the SME performance. The results have also indicated that the directors' do not greatly affect the performance owing to several careers related to the outside external environment of the SME.
\end{abstract}

Keyswords: Governance, Ownership structure, Board of directors, CEO, Performance, SME

\section{Introduction}

The governance subject has often been considered was acknowledged as a major problematic issue affecting that touches all types of enterprises particularly the SME. In fact, it is more specific to the context of small and medium size firms than that of large enterprises. In this respect, the SME specifities have to be considered separately i.e without assimilating or interacting them with those of large-size business. As a matter of fact, the SME might apply similar governance codes to those pertaining to large businesses, yet, several elements which have a remarkable impact on affecting their structures and systems of governance must be taken into account (OCDE, 2006).

Hence, the SME environment has recently made of this subject matter a vital issue worthy of interest. Actually, economists underline the essential role these enterprises play in creating employment, enhancing growth, innovation, exports etc. Regarding the underdeveloped countries, the SME has a paramount importance, and even more critical role as far the economy is concerned.

In fact, The SMEs have some specific characteristics distinguishing them from large enterprises namely, the strategies of planning and the survey of the practices of management (Kerr, 2006).

Indeed, as regards the SME, the separation between the propriety and the decision making does not exist (Charreaux, 1998). The main managerial functions along with the capital are most frequently concentrated in the hands of the controlling owner and/ or his family (Ben Hamad, 2004).

The importance accorded to these mechanisms is reflected by some diverse initiatives aiming at explaining the good practices of the governance (Aguilera and Cuervo-Cazurra, 2004). Recently, the interest accorded to the mechanisms of governance and their effects on the companies' financial performance have taken a primary international dimension of first rank. It is worth noting that the ownership structure, the board of directors as well as the directors' characteristics constitutes three central elements in the survey of the SME governance.

In this context the problematic of this article deals with examining the extent to which such governance mechanisms could influence the SME financial performance as the ownership structure, the board of directors and the directors' characters. 


\section{Corporate Governance}

A big number of definitions of corporate governance were advanced during the years. The traditional definition is in connection with the protection of the interests of shareholder (Tirole, 2001) and has some roots in the question of separation between management and control (Berle and Means, 1932).

The corporate governance is more than an analysis of the effect of separation and control in a modern society. For example, the OCDE (2004) defined the corporate governance like:

"Corporate governance deals with the rights and responsibilities of a company's management, its board, shareholders and various stakeholders. How well companies are run affects market confidence as well as company performance. Good corporate governance is therefore essential for companies that want access to capital and for countries that want to stimulate private sector investment. If companies are well run, they will prosper. This in turn will enable them to attract investors whose support can help to finance faster growth.

Poor corporate governance on the other hand weakens a company's potential and at worst can pave the way for financial difficulties and even fraud." (OCDE, 2004).

The exercise of the governance of the big enterprises could also be applied to the SME (Yacuzzi, 2009).

\section{Governance of SME}

The mechanisms of governance of the SME have for object not only the protection of the contribution of the shareholders but also the transactions between the enterprise and the different stakeholders, that it is the directors, the creditors, the salaried employee, the customers, the suppliers and, with a very general way, the societal environment. These mechanisms could be external and internal.

\subsection{The external mechanisms}

In the setting of the SME, the market of directors plays a regulating role in the value of leader that depends of the financial achieved performance. The obstacles met by the SME are the cognitive capacities of management. The complexity of an organization grows with its size. And when this complexity passes the capacities of treatment of the information of the managers, they don't control what happened in the enterprise: the mistakes increase, the quality degrades and the growth decrease (Penrose, 1959).

The SME meet many obstacles who are financial nature. When they look for financings, they don't have access in general only for the credit banking, whereas their more important competitors can inquire the financial markets (Fendel and Frenkel, 1998).

\subsection{The internal mechanisms}

In the setting of the ownership structure, the majority of the directors are shareholders (Charreaux, 1998). Indeed, the familial SME owners could benefit giving a lot of it involvement to their directors. This implies that the enterprise could use the exceptional facilities and the capacities that the owner uses in order to succeed the enterprise (Randoy and. Goel, 2003).

The board of directors represents the main organ of control, complementary to the external mechanisms. The role of the board spreads to several functions within the SME: the administration of the enterprise, regaining some roles of surveillance, control of the directors and the setting up of the enterprise strategy, the organization of relations between the enterprise and its environment, the capitation of the external facilities, the recompense the directors, dismiss them, and ratify and control the important decisions take by the direction (Van Gils and al, 2006).

\section{Governance and performance of the SME}

Generally, the SME has structures of the simpler governance than the big enterprises. Also, their questions of governance are greatly simpler that in the big enterprises (IBRF, 2002). In other words, the small enterprises don't expose of systems of complex management in order to compete with the big enterprises. This comes back to several carriers of comparison.

In the first place, the restricted options to the size and to the constraints of resources and the strategies chosen by the small enterprise influence the performance. For example, the SME could not have of necessary facilities or managerial expertise in order to use some strategies of the diversification.

In second place, the interpersonal character, and the interaction found in the small compared enterprises to the big enterprises should lead to a biggest adequacy between the owners, the directors, and the employees of SME, it is the argument of the theory of the intendance (Neilson, 1974).

These factors suggest that the effects of the theory of agency on the small enterprise could be different that the effects found in the survey of big enterprises.

\subsection{Relation between ownership structure and performance of the SME}

The ownership structure is composed of different types of shareholders: the familial, managerial and the block ownership.

4.1.1 The familial and the performance of SME 
Recently, several researchers concluded that the family is viewed like an important variable in the research of organization (Bartholomeusz, and Tanewski, 2006).

For example, Daily and Dollinger (1992) show that: The small enterprise, in particular the familial enterprise, possesses an individual in most of the case, the owner who takes in loads of all the process of the enterprise. These enterprises, therefore, provide a rich region of hypotheses to the topic of the separation between propriety and control. It is in the SME that there is links between the ownership and performance that could be observed more easily.

These authors examine the relation between the ownership structure and the growth of the sales of 186 industrial SME. The enterprises in the survey is classified in two classes, they are controlled by the family owner or professionally controlled (the director have no part of the capital). The result doesn't reveal any difference statistically considerable in the evolution of the sales between the two groups.

Seen the divergence of these different works, Joseph and al (2009) put three criteria's that the familial enterprises must in value: the directives of clear governance, the diversification and the technological innovation; the three elements become harder when the quality of the governance is bad, and when it is superior, they are going to improve the functions of the enterprise and the well-being of the family.

\section{Hypothesis 1: The familial ownership has a positive influence on the performance of SME.}

\subsubsection{The managerial ownership and the performance of the SME}

The relation between managerial ownership and the performance was a center of empiric research since Jensen and Meckling (1976) who suppose that managerial ownership is an important mechanism in order to align the interests of directors and shareholders.

These authors consider that the managerial ownership is a mechanism of internal control for the problems of the agency, their survey leads that the managerial ownership affects the SME performance positively because the alignment of the interests of directors and shareholders reduced the costs of agency.

O'Regan and al. (2005) examine the relation between the ownership structure and the financial performance, measured as profit by employee by year, in a sample of 207 SME of electronics and mechanics in Britain. The enterprises in the survey are classified as enterprises with directors owners or enterprises with directors no owners. The result shows that the enterprises with director owner are more competitive that the SME professionally controlled.

\section{Hypothesis 2: The managerial ownership has a negative influence on the performance of the SME.}

\subsubsection{The ownership of the block holders and the performance of the SME}

We put the accent now on the specific role of block holders and their effect on the profitability of the enterprise and the value of enterprise. The ownership of block holder permits a best allocation of the mechanisms of external control without that the director take a part in the capital structure (Shleifer and Vishny, 1986). In this case, the ownership of block holder could reduce some costs of agency, by managing actively and intervening in the major decisions of the enterprise in order to increase the value of enterprise and its performance (kang, 2000). It implies that the Chief Executive Officer (CEO) and the members of the board are forced to act with the interests of the majorities shareholders.

Hansen (2007) demonstrates that the concentration of the ownership is more elevated in the industries of construction. The businesses who have some changes during the last four years are generally who displace to more condensed structure. They are less competitive. For him, the SME having some financial problems have the worst performance and stability in the profit. They achieve feeble profits and the societies in the service sector are more competitive.

On the other hand, McConnell and Servaes (1990) suggest that the block holders could intervene in order to encourage the profitable strategies. Their ownership could reduce the costs of agency and this by the control and the intervening in the major decisions of the enterprise in order to increase the value of the enterprise and its performance.

\section{Hypothesis 3: the ownership of block holder has a positive influence on the performance of the SME.}

4.2 The board of directors and the performance of the SME

The survey of boards, a central question in the governance of undertaking, also occupies an important place in the survey of governance of SME. Among the different features of board who could assign the performance of the SME, we find the size, and the number of present administrators in the board.

4.2.1 The size of board of directors and the performance of the SME

The role of board of directors was an important region of research of the management. However, less attention was lent to the role of board in the SME. In SME, the resources and the control offered by the directors could be very different that those found in the big enterprises. 
For the SME, the one of transitions are most important is the unique director owner to a larger board: from a person to a team. This change was called by various terms, for example, the transition from a transformational direction to the transactional direction (Arthur and Hendry, 1990).

These arguments suggest that, beyond of a certain business dimension, or beyond of a period of time when the particular skills of owner and of the direction was crucial, the enlarging of a team of management could improve the performance. Bennett and Robson (2004) show how the role of board of directors acted like a substitute with the strategies developed by the SME in order to consult the external board or in order to develop the levels of knowledge of the internal managers. Their result shows that the size of board has an important influence on the strategy of innovation.

\section{Hypothesis 4: The size of board of directors has a positive influence on the performance of the SME.}

\subsubsection{The composition of board of directors and the performance of the SME}

Among the different dimensions of boards of directors, the composition of board is the most fundamental elements. In explaining the majority of efforts of the research on the boards, the number of papers who studies the composition of board, the affiliation of directors, and the distinction between to the inside to the outside of board becomes interesting (Finkelstein and Hambrick, 1996).

Installing a board of directors with the independent administrators could be an efficient instrument in order to decrease the costs of agency (Fama and Jensen, 1983). The independent directors are expected to supervise the interests of management more efficiently that the dependent directors.

It exist three big arguments of thinking that the external administrators are more attentive than the other administrators:

> «They insist on the financial performance, who is a central component of control (Fama and Jensen, 1983);

$>$ «More than the internal administrators, they are susceptible of separating the directors who got less performances (Coughlan and Schmidt, 1985);

$>$ «They want to protect their personal reputation, which is going to incite them to control (Fama and Jensen, 1983).

Consequently, external administrators increasing proportion increases the capacity of board of being objective concerning the control of the directors (Fama, 1980) and, in extreme cases, of replacing some leaders less skilled.

Liang and Li (1999), basing on sample of 228 private SME in Shanghai and China, study the relation between the structure of board and the performance of enterprise. They find that the presence of outside directors is associate positively with an elevated output of funded capitals, though most of the enterprises display a board dominated by the internal people to the organization as well as the high technology has a tendency to increase the performance.

Hypothesis 5: The presence of the independent administrators has a positive influence on the performance of the SME.

\subsubsection{The duality of directors}

In the literature concerning the separation of the stations of chief of the direction and of president of the board, the opinions are different: some sustain the duality, some others denounce it.

The duality of the CEO exists when the CEO of a society serves also of president to the board of directors. The duality corresponds therefore to the situation where the director occupies also the station of president of board (Boyd, 1995).

The potential advantage of having the same person who filled the two positions is that they should expose a biggest understanding and acquaintance of the environment of the company.

On the other hand, a big number of authors affirm that the duality appears like a obstacle to the separation of the functions of decision and control. Fama and Jensen (1983) discuss that it's more difficult of controlling in board dominated by internal directors.

Jensen (1993) recommends for separating the position of president of board and the director of the direction in order to reduce the discretionary power of director and to assure the efficiency of the boards. In the theory of agency, in order to improve the level of control, the functions of control and decision are separated.

Hypothesis 6: The duality of leader has a negative influence on the financial performance some SME.

\subsection{The characters of directors}

\subsubsection{The age of directors}

The literature suggests that the age of directors can play on the value created by the enterprise (Hambrick and Mason, 1984). 
Indirectly bound to the age of leader, the notion of preeminence in the post (job tenure) seems an important criteria in order to analyze the contribution of directors to the creation of value of the enterprise (Boeker 1997), supposing a positive relation between the creation of value and the age on the hand, or the seniority on the other hand:

\section{Hypothesis 7: The age of directors has a positive impact on the financial performance of SME.}

4.3.2 The qualification of the directors and the performance of the SME

The expertise and the development of the human resource are important for the commercial growth. For example, the weak levels of formation of the directors in the Britain compared with the USA, the Japan, the Germany or the France, was suggested like a major deficit in the SME (Hendry and al, 1991).

Therefore, the level of formation can have a strong influence on the performance because of the positive relation proven of high levels of education for the entrepreneurs and their good motivation in order to use the external information, develop some networks, and use of counselors or in order to supervise (Lybaert, 1998).

\section{Hypothesis 8: The levels of qualification of the leaders have a positive influence on the performance of the} SME.

\section{Methodology of research and results}

\subsection{Choice of the sample}

The population considered in this survey is the small and means enterprises in the Tunisian context. Basing on Agency of Promotion of the Industry (API), is considered like SME all enterprise which the number of the employees doesn't pass the 200 employees. So, it is the criteria who specify the gate separating the big and small enterprises.

The data collection was realized by a questionnaire including 4 composed parts like follows:

1. Identification of the enterprise: general ideas of the enterprise; its sector of activity, its date of creation, its statute.

2. Questions relative to the ownership structure; it was about the composition of the propriety and its influence on the direction of the enterprise.

3. Questions relative to the features of the boards; this theme provided a general discussion on the working of boards. It treats the topics of the independence of boards, its activities, its composition, the formation of the administrators.

4. Information relative to the performance of the enterprise: allows valuing the growth and the profitability of the enterprise by different financial measurements.

\subsection{The econometric model}

The objective of this article is explaining the financial performance of SME by the variable of the ownership structure, the variable relative to the board and the characters of the directors.

Performance $_{t}=\beta 1+\beta 2 C A F A M+\beta 3 C A P D I R+\beta 4 B L O C+\beta 5$ TCA $+\beta 6 M E X T+\beta 7 D U A L+\beta 8 Q U A L+\beta 9$ $A G E D I R+\beta_{10} T A I L L E+\beta_{11} A G E+\beta_{12} D L M T+\beta_{13} D C T+\varepsilon_{t}$

The following table presents the measurements of the performance.

\section{Insert table 1 here}

The following table presents the different independent variable.

\section{Insert table 2 here}

\subsection{Interpretation of the results}

The sample of the search is trained of 50 industrial SME enterprises situating in the region of Sfax. It was selected in function of the easiness of access to the enterprises.

The following table present the distribution of the sample by sector of activity.

\section{Insert table 3 here}

The enterprises of our sample belong are SME. More than the half (43 SME) has a lower strength to 50 employees. Only 7 of between them has more than 50 employees. The ventilation of the sample by sector of activity according to a classification by economical nomenclature reveals that most of the sectors of activity is represented in our [panel], to the exception of the financial activities. Indeed $34 \%$ some SME of our sample makes left some various domains, $18 \%$ of sector of the materials of construction and $14 \%$ Mechanical, $12 \%$ textiles, $12 \%$ electric, $10 \%$ agro alimentary.

In this that follows, we try to comment the results of the different regressions. We analyse the impact of the different variable of the ownership structure, board of directors, and characters of directors.

\section{Insert table 4 here}

The following table sums up the different results of the independent variable. 
The following table presents the results of the regression with of the variable of control

\section{Insert table 5 here}

To the light of these results, we could advance the following commentaries.

Comparing the two tables, we remark that the introduction of control variable as the age, the size, the short term debt, and the long term debt improve the three models of regression.

The majority of shareholders could do exercises a pressure on the leaders to maximize the value of the enterprise, without having to preoccupy some managerial interests. Many authors of the theory of agency as Demsetz (1983), Shleifer and Vishny (1986), affirm that the concentration of capital participle to the efficiency of control of management of the leaders by the shareholders. The owners of the enterprise detaining an important part of capital have a certain interest to invest in the control because the resulting gains of this action will come back to them in big part.

In the current analysis, the property of the majority of shareholders is the property of the shareholders who have more than $50 \%$ of capital of the enterprise. The results of the regressions show that the coefficient of the property of the major shareholders is negative and no significant. We must to reject our third hypothesis.

The coefficient of the variable CADIR is negative for the performance financial ROE and ROE and significant with a level of risk of $10 \%$. Therefore, the hypothesis 2 is validated.

According to the results of the analysis of the multiple regressions, the influence of CAFAM on the performance is positive but this relation is not significant.

Consequently, we can say that our hypothesis 1 according to the importance of familial character affects the financial performance of the enterprise is not confirmed because it is no significant. But it is necessary to reminder that consistently to our predictions; the familial character should influence positively the financial performance as several studies demonstrated that the familial enterprises are more grateful than the no familial enterprises and advanced the explanation through the familial character. Randoy and Goel (2003) find in their analyses in using the multiple regressions, that a level raised of internal property is correlated statistically with output of enclosed elevated capital when the SME is controlled by the family owner. As for the family owner doesn't hold the control, the ownership structure is correlated statistically with the low output capital.

The associate coefficient to the variable MEXT has a positive and significant sign with ROS to a degree of significance of $10 \%$. Therefore, the presence of the members of the external administrators has a positive impact on the financial performance SME. This result confirms those found by Pearce and Zahra (1992). In fact that they are external of the enterprise, these administrators are susceptible of having some experiences, some expertise and varied acquaintances, this who allows them to attend the direction by the appraisal and the counsels. Finally, the external members permit the creation of the relations between the enterprise and its external environment facilitating the access to some facilities and applicable information concerning the suppliers, the customers and the financial opportunities. Then, the hypothesis 5 must be validated.

The hypothesis 6 according to the duality of the functions of leader (DUAL) and of president of board of directors influencing the financial performance SME negatively is not validated. Indeed, the results make to appear that the coefficient associated to the variable DUAL is statistically no significant.

The variable corresponding TCA to the size of board of directors is significant for the ROS performance. Therefore, the hypothesis 4 is validated for this type of performance. Such a result could be explained that $83 \%$ of the sample has a board of directors composing the maximum 5 members. So, the problems of coordination and of communication, which could emerge within the board of directors of big size don't present. In this sense, Corbetta and Tomesselli (1996) affirm that a board formed from 4 to 7 members permits a good presentation of the different shareholders and he guarantee at the same time the conditions of good working.

In our model of the financial performance of the enterprise, we introduce two variables relative to the entrenchment of directors: the age of director and her qualification. These variables are defined as the respective logarithms of the age and of the grade of director and this in order to reduce the mistakes of measurement. Eaton and Rosen (1983) affirm that the age of director reflects her degree of aversion to the risk. This variable estimates the level of the experience of the leaders and it assigns their level of remuneration. The overtaking of the directors for the age of the retirement is an indicator of entrenchment. Their power is sufficiently strong in order to convince the partners to accept the continuity of their service in spite of the incurred risks. The sample presents $15 \%$ of directors passing the age of the departure (60 years).

The results of the regressions show that the coefficient of the age of directors and her qualification is not significant. This corroborates the results of Eaton and Rosen (1983) affirming that the age is an indicator of the entrenchment of the directors. Therefore, the hypothesis 7 is rejected.

The qualification of directors and the variable ROA are statically correlated. Consequently, we can validate the hypothesis $8.60 \%$ of directors have scientific elevated degrees, and the level of expertise of the directors intervenes in the improvement of the financial performance. The disciplinary role exercised by the market of work is down by the weak sent signs by the SME on the quality of the managers. So, the bad financial 
performance SME could be explained by several external carriers as the economical conjuncture, but it is difficult of discerning the part of responsibility of the directors.

We note, according to the table 5 , that the relative coefficient to the variable size of the business is positive and no significant. The size of the enterprise doesn't have an effect on the performance of the SME. We notice that the age of the enterprise doesn't have of significant effect on the performance of SME. Concerning the debt, we notice that the variable that long term debt is significant with a negative sign with all the dependent variable. The variable short term debt (DCT) has a positive effect on the ROA performance. This result explain that $60 \%$ of SME choose the debts to short term and $48 \%$ of the sample make some debts to long term.

\section{Conclusion}

It is worth noting that the question of corporate governance which constitutes a privileged and major subject matter dealt with by the former economic and financial literature, finds its origins in" The modern corporation and private propriety» of Berle and Means (1932). The latter have stressed the problems arising from the separation of the functions of decision making and propriety. Actually, the conflicts between shareholders' and CEO roles emerging from the separation of their respective functions have led to the creation bases of the agency theory.

As for our survey, it contributes in highlighting some structural results concerning the control mechanisms relevant to the SME performance. However, the thesis of a positive effect of the family capital on the SME performance appears to be rejected in the Tunisian context. As for the directors who detain parts of the company capital, they seem to have some negative effects on the business performance. In fact, the agency problems appear to be very rare and limited within the SME, owing to the fact that in most these enterprises, the CEO is the owner of the enterprise (Charreaux, 1998).

With regards to the characteristic features of directors, it is noticeable that the board size along with the presence of some external members have had a positive effect on the SME performance. This result highlights the important role which could be played by the board of directors as a control mechanism within an SME. This role is clearly apparent in the strategic decisions to be taken as well as the resolution of constraints.

The third element of governance is the director. Although the leader occupies an important place due to this involvement in the daily functioning and development of the SME, the relative variable of age does not seem to have a significant effect on the SME performance. This result is due and related to the intervening of such external mechanisms as the employment market. Therefore, the SME governance appears to be influenced and characterized by a discipline exercised by the inefficient or limited markets. Consequently, the internal mechanisms are considered to have a paramountly vital importance as regards the SMEs governance and the preservation of their performances.

On the basis of these various results, it is worth mentioning that the Tunisian SME occupies the second rate of progression according to the progression matrix of corporate governance for the non-listed companies (Abouzaid, 2008). This rank is crucially important as it ensures the prevalence of efficient signs and initiative measurements of effective positive practices of governance.

\section{References}

Abouzaid, S. (2008). IFC Family Business governance Handbook. International Finance Corporation, 66p.

Aguilera, R. V., and Cuervo-Cazurra, A. (2004). Codes of Good Governance Worldwide: What is the Trigger?. Organization Studies, Vol. 25, no. 3, pp. 415-443

Arthur, M., and Hendry, C. (1990). Human Resource Management and the Emergent Strategy of Small to Medium Sized Business Units. International Journal of Human Resource Management, 1 (3), pp. 233-250.

Bartholomeusz, S., and Tanewski, G. A. (2006). The relationship between family firms and corporate governance. Journal of Small Business Management, 44(2), pp. 245-267.

Ben Hamad, S. (2004). Financial decisions and global financial behaviour of Tunisian small and medium enterprises. Thesis of doctorate, 323p.

Bennett, R. J., and Robson, P. J. A. (2004). The Role of Trust and Contract in the Supply of Business Advice. Cambridge Journal of Economics, 28(4), pp. 471-88.

Berle, A. A., and Means, G. C. (1932). "The Modern Corporation and Private propreity" Revised edition 1967, Harcourt, Brace et World, Inc, New York.

Boeker, W. (1997). Strategic Change: The Influence of Managerial Characteristics and organizational growth. Academy of Management Journal, Vol. 40, n1, pp. 152-170.

Boyd, B. K. (1995). CEO duality and firm performance: A contingency model, Strategic. Management Journal, Vol. 16, pp. 301-312.

Charreaux, G. (1998). Governance of SME-SMI », in PME-PMI: Paris, Economica, pp. 109-116.

Corbetta, G., and Tomaselli, S. (1996). Boards of Directors in Italian Family Businesses. Family Business Review, 
4 (IX), pp. 403-421

Coughlan, A., and R. Schmidt. (1985). Executive compensation, management turnover, and firm performance: An empirical investigation. Journal of Accounting and Economics, Vol. 7, pp. 43-66.

Daily, C.M., and Dollinger, M.J. (1992). An empirical examination of ownership structure in family and professionally managed firms. Family Business Review, vol. 5, no. 2, pp. 117-136.

Eaton, J and Rosen, H.S. (1983). Agency, delayed compensation, and the structure of executive remuneration. Journal of Finance, 38, n5, December, pp. 1489-1505. Economica.

Fama, E. F., and Jensen, M. C. (1983). Separation of ownership and control. Journal of Law and Economics, 26p, pp. 301-325.

Finkelstein, S., and Hambrick, D.C. (1996). Strategic Leadership: Top Executives and Their Effects on Organizations. West, Minneapolis/St. Paul.

Hambrick D.C., and Mason, P. (1984). Upper echelons: The organization as a reflection of its top managers. Vol. 9, n2, pp. 193-206.

Hansen, M.D. (2007). Small Firm Performance and Ownership Structure", School of Economics and Management and Institute of Business and Technology, University Aarhus and Centre for Industrial Economics, University of Copenhagen, Denmark, 17p Harvard Business Review.

IBRF. (2002). The International Bank for Reconstruction and Development/The World Bank' World Development Report 2002: Building Institutions for Markets, Oxford University Press, New York, NY.

Jensen, M.C. (1993). The Modern Industrial Revolution, Exit, and the Failure of Internal Control Systems. The Journal of Finance, Vol.48 (3), pp.831-880.

Jensen, Michael C., and William H. Meckling. (1976). Theory of the firm: Managerial behavior, agency costs and capital structure. Journal of Financial Economics, 3, 305-60.

Joseph A. McCahery and Erik P.M. Vermeulen. (2009). The Corporate Governance Framework of Non-Listed Companies", University of Amsterdam - Business School and Tilburg University - Center for Company Law Department of Business Law, p. 15.

Kang, D. (2000). The impact of activist institutional investors on performance in public corporations: a study of the U.S. Fortune 500, 1982-1994", Best Pap. Proc.-Acad. Manage., 1-6. 636 T. Randøy, S. Goel. Journal of Business Venturing 18 (2003), p 619-637.

Kerr, I. R. (2006). Leadership strategies for sustainable SME operation. Business Strategy and the Environment, Vol 15 Issue 1, Pages, pp.30-39.

Leland and Pyle. (1977). Informational Asymmetries, Financial Structure, and Financial Intermediation. Journal of Finance, vol. XXXII, no. 2, pp. 371-387, septembre.

Liang, N., and Li, J. (1999). "Board Structure and Firm Performance: New Evidence from China's Private Firms", Paper presented at the Academy of Management Annual Conference, Chicago, USA, August 7-10.

Lybaert, N. (1998). The information use in a SME: its importance and some elements of influence. Small Business Economics, 12 (2), 171-191.

McConnell, J.J., and Servaes, H. (1990). Additional evidence on equity ownership and corporate value. J. Financ. Econ, 27 p, p 595-612.

McMahon. (2007). Ownership structure, business growth and financial performance amongst SMEs from Australian's business longitudinal survey. Flinders Business School Research Paper Series, 39p.

Neilson, E. H. (1974). Contingency theory applied to small business organizations. Human Relations, Vol. 27, No. 4: 357-379.

O'Regan, N. Sims, M., and Ghobadian, A. (2005). High performance: ownership and decision-making in SMEs. Management Decision, vol. 43, no. 3, pp. 382-396.

OCDE. (2006). Corporate governance from non-listed companies in emerging markets. [Online] Available: www oecd.com

OECD. (2004). OECD Principles of Corporate Governance. [Online] Available: www.oecd.com, OECD, 2004.

Pearce, J.A., and Zahra, S.A. (1992). Board composition from a strategic contingency perspective. Journal of Management Studies, Vol.29, pp. 411-438.

Penrose, E. (1959). The theory of the growth of the firm. Contribution to Political Economy revue.

Randoy, T and Goel, S. (2003). Ownership structure, founder leadership, and performance in Norwegian SMEs: implications for financing entrepreneurial opportunities. Journal of Business Venturing, 18p, pp. 619-637.

Shleifer, A., and Vishny, W. (1986). Large Shareholders and Corporate Control. The Journal of Political Economy, Vol. 94, No. 3, Part 1., pp. 461-488. 
Sundaramurthy, C., Rhoades, D.L., and Rechner, P.L. (2005). A meta-analysis of the effects of executive and institutional ownership on firm performance. Journal of Management Issues, vol. 17, no. 4, pp. 494-510.

Van, G., Heuvel, J., and Voordeckers, W. (2006). Board Roles in Small and Medium-Sized Family Businesses: Performance and Importance. Hasselt University, Faculty of Applied Economic Sciences, Belgium, 36p.

Yacuzzi, E. (2007). A primer on governance and performance in small and medium-sized enterprises. 29p.

Yacuzzi, E. (2009). A Governance Indicator for Small and Medium-Sized Enterprises. Univercity of CEMA Working Paper No. 390.

Zafft, R. (2002). "Large, Family -Run Firms: the OECD Experience", The Fourth Asian Roundtable on Corporate Governance, Shareholder Rights and the Equitable Treatment of Shareholders, OECD, Mumbai, India, pp. 11-12

November.

Table 1. The measurements of the performance

\begin{tabular}{|c|c|}
\hline Return on sales & $\mathbf{R O S}_{=}(\operatorname{sales}(\mathrm{t}) / \operatorname{sales}(\mathrm{t}-1)-1) * 100$ \\
\hline Return on assets & $\mathbf{R O A}=$ Net result $/$ total assets \\
\hline Return on equity & $\mathbf{R O E}=$ Net result/ equity \\
\hline
\end{tabular}

Table 2. Presentation of the variable

\begin{tabular}{|c|l|}
\hline CAFAM & The proportion of capital detained by the members of the family \\
\hline CADIR & The proportion of capital detained by le director of the entreprise \\
\hline BLOC & The proportion of capital detained by le principal owner \\
\hline TCA & The number of members of board of directors \\
\hline MEXT & The number of external members \\
\hline DUAL & $\begin{array}{l}\text { It takes the value } 1 \text { if the function of CEO and president of board is } \\
\text { accumulated by the same person, and 0 otherwise }\end{array}$ \\
\hline QUAL & The level of expertise of the directors \\
\hline AGEDIR & The age of directors. \\
\hline
\end{tabular}

Table 3. Distribution of the sample

\begin{tabular}{|l|c|c|}
\hline \multicolumn{1}{|c|}{ Sector of activity } & Frequency & Proportion \\
\hline agro alimentary & 5 & 10 \\
\hline Electric & 6 & 12 \\
\hline Textile & 6 & 12 \\
\hline Technique & 7 & 14 \\
\hline Material of construction & 9 & 18 \\
\hline Divers & 17 & 34 \\
\hline Total & 50 & 100 \\
\hline
\end{tabular}

Table 4. The results of the regression

\begin{tabular}{|c|c|c|c|c|c|c|}
\hline & \multicolumn{2}{|r|}{ ROS } & \multicolumn{2}{|r|}{ ROA } & \multicolumn{2}{|r|}{ ROE } \\
\hline & B & Signification & B & Signification & $\bar{\beta}$ & Signification \\
\hline Constante & 0,494 & 0,607 & 2,258 & 0,173 & 2,942 & 0,030 \\
\hline CAFAM & 0,234 & 0,190 & 0,101 & 0,740 & 0,113 & 0,644 \\
\hline CADIR & $-0,011$ & 0,956 & 0,611 & 0,090 & 0,631 & 0,031 \\
\hline BLOCK & 0,098 & 0,918 & 2,308 & 0,164 & 2,338 & 0,081 \\
\hline TCA & 0,417 & 0,066 & 0,131 & 0,732 & 0,254 & 0,409 \\
\hline MEXT & 0,256 & 0,078 & 0,320 & 0,193 & 0,292 & 0,141 \\
\hline DUAL & $-0,276$ & 0,331 & 0,315 & 0,515 & 0,036 & 0,925 \\
\hline QUAL & 0,112 & 0,408 & 0,142 & 0,538 & 0,089 & 0,632 \\
\hline $\mathbf{R}^{2}$ & \multicolumn{2}{|r|}{0,356} & \multicolumn{2}{|r|}{0,319} & \multicolumn{2}{|r|}{0,315} \\
\hline DW & \multicolumn{2}{|r|}{2,229} & \multicolumn{2}{|r|}{1,792} & \multicolumn{2}{|r|}{2,126} \\
\hline
\end{tabular}


Table 5. Results of the regression after introducing of the variables of control

\begin{tabular}{|c|l|l|l|l|l|l|}
\hline \multirow{2}{*}{$\begin{array}{l}\text { independent } \\
\text { Variables }\end{array}$} & \multicolumn{7}{|c|}{ ROS } & \multicolumn{2}{|c|}{ ROA } & \multicolumn{2}{c|}{ ROE } \\
\cline { 2 - 7 } & $\boldsymbol{\beta}$ & signification & $\boldsymbol{\beta}$ & Signification & $\boldsymbol{\beta}$ & Signification \\
\hline Constante & 1,450 & 0,392 & 1,116 & 0,511 & 2,788 & $\mathbf{0 , 0 6 0}$ \\
\hline CAFAM & 0,140 & 0,403 & 0,220 & 0,252 & 0,172 & 0,293 \\
\hline CADIR & $-0,018$ & 0,891 & $-0,090$ & 0,523 & $-0,210$ & $\mathbf{0 , 0 8 7}$ \\
\hline BLOCK & $-0,790$ & 0,302 & $-0,807$ & 0,477 & $-1,344$ & 0,169 \\
\hline TCA & 0,576 & $\mathbf{0 , 0 1 5}$ & $-0,147$ & 0,607 & $-0,217$ & 0,375 \\
\hline MEXT & 0,325 & $\mathbf{0 , 0 2 1}$ & 0,277 & 0,124 & 0,264 & $\mathbf{0 , 0 8 6}$ \\
\hline DUAL & $-0,189$ & 0,545 & 0,388 & 0,367 & 0,537 & 0,146 \\
\hline AGEDIR & $-0,002$ & 0,988 & 0,150 & 0,407 & 0,203 & 0,191 \\
\hline QUAL & 0,109 & 0,444 & 0,530 & $\mathbf{0 , 0 0 6}$ & 0,192 & 0,227 \\
\hline TAILLE & 0,021 & 0,822 & 0,129 & 0,501 & 0,092 & 0,570 \\
\hline AGE & 0,083 & 0,579 & $-0,048$ & 0,676 & $-0,008$ & 0,931 \\
\hline DLMT & $-0,143$ & $\mathbf{0 , 0 2 4}$ & $-0,166$ & $\mathbf{0 , 0 4 2}$ & $-0,115$ & $\mathbf{0 , 0 9 4}$ \\
\hline DCT & 0,150 & $\mathbf{0 , 0 7 3}$ & 0,077 & 0,469 & 0,042 & 0,641 \\
\hline R & & $\mathbf{0 , 4 3 1}$ & & $\mathbf{0 , 4 0 9}$ & & $\mathbf{0 , 3 8 3}$ \\
\hline Durbin-watson & & $\mathbf{2 , 2 5 5}$ & & $\mathbf{1 , 9 3 1}$ & & $\mathbf{2 , 3 1 0}$ \\
\hline
\end{tabular}

